\title{
PRACTISE OF ORGANIZING LAKE COMMERCIAL FISH FARMS IN CONDITIONS OF LAKE OZGENT ${ }^{1}$
}

\author{
N. B. Bulavina, T. T. Barakbayev, G. Zh. Iskhakhov, A. A. Mukhramova \\ Fisheries Research and Production Center, LLP, \\ Almaty, Republic of Kazakhstan
}

\begin{abstract}
The article presents the results of the researches conducted on Lake Ozgent (the Kyzylorda region). The data on hydrochemical regime of the lake, ionic composition, composition of biogenous compounds, oxygen and thermal regimes were collected and analysed. There has been done the assessment of food supply and current state of the ichthyofauna. According to the obtained data, the recommendations about using Lake Ozgent were made, the recommended meliorative events (meliorative fishing, repair of hydroconstructions) were held and stocking the fishing material of carp was carried out. Based on the work results it has been established that in the conditions of Lake Ozgent the pure gain in 5 months of cultivation (on extensive technology when using only the natural food supply) made $385.6 \mathrm{~g}$ in a carp, $301.4 \mathrm{~g}$ in a white silver carp and $428.7 \mathrm{~g}$ in a grass carp. In the full catch of commodity fish species, the overall fish productivity of Lake Ozgent will make $101.9 \mathrm{~kg} / \mathrm{hectare}$, of them carp will take $43.4 \mathrm{~kg} /$ hectare, grass carp - $13.5 \mathrm{~kg} /$ hectare and white silver carp - $45 \mathrm{~kg} /$ hectare. The growth of the grown-up fish in Lake Ozgent corresponds to biotechnical standards of fish cultivation in the in polyculture of the feeding lakes.
\end{abstract}

Key words: fishing, Lake Ozgent, hydrochemical parameters, carp species, growth.

For citation: Bulavina N. B., Barakbayev T. T., Iskhakhov G. Zh., Mukhramova A. A. Practise of organizing lake commercial fish farms in conditions of Lake Ozgent. Vestnik of Astrakhan State Technical University. Series: Fishing Industry. 2021;2:90-96. (In Russ.) DOI: 10.24143/20729502-2021-2-90-96.

\section{Introduction}

To ensure the economic efficiency of the developed lake commercial fish farms (LCFF), it is necessary to improve biotechnical schemes and techniques of lake-commodity fisheries adapted to the conditions of a particular region and a particular lake. As showed the practice of commodity fish breeding, the biotechnical schemes and receptions of aquaculture developed in other countries and earlier in Kazakhstan are not always effective in modern economic conditions of our country, and demand adaptation to the conditions of the particular reservoirs. The Kyzylorda region has the optimal climatic conditions for lake-commodity fisheries, which allows to consider this region as the most perspective for development of lake-commodity fisheries, able to receive valuable fish products in a year. The region has considerable water areas, which are very perspective and economic for maintaining LCFF.

\section{Materials and methods}

There were selected the hydrochemical, hydrobiological, fish-breeding and biological and icthyological samples in the necessary volume. Determining the number and location of stations for sampling was carried out, according to the methodical recommendations on collecting and processing the materials during hydrobiological and hydrochemical research [1-3]. The analysis of the hydrological mode of reservoirs was carried out by measuring the average and maximum depths and water level. Tests were selected at the stations from a surface layer. Hydrochemical researches included definition of the gas mode of water, as well as its physical and chemical properties. Also the ionic and biogenic composition of water was identified. Sampling and defining the physicochemical, hydrochemical indicators (salt structure) were made, according to the typical state standard specifications and techniques, for classification of waters there was used O. A. Alekin's scheme [2]. Quantitative samples of zoo-

\footnotetext{
${ }^{1}$ This research has is funded by the Ministry of Ecology, Geology and Natural Resources of the Republic of Kazakhstan (Grant No. BR10264236 Scientific-technological support for the integrated development of aquaculture in Kazakhstan through the implementation of innovative technologies and new fish-farming objects).
} 
plankton and zoobenthos were taken and treated in accordance with the "methodological manual for hydrobiological fisheries studies of the water bodies of Kazakhstan (plankton, zoobenthos)" [3]. Zooplankton was selected by Jedi's network with a vertical stretching from a bottom to a surface. The samples were processed in Bogorov's camera; all species of zooplankton were counted and measured. The definition of various groups of organisms was carried out on the corresponding determinants [4-6]. For calculating the biomass there were used the equations given in the work of $\mathrm{E}$. V. Balushkina and G. G. Vinberg [5]. The macrozoobenthos was selected by Petersen's bottom-grab. The definition of organisms was carried out by the available determinants [4-6]. The biomass of separate groups was defined by weighing the torsion scales. An assessment of level of a trophy of communities is given according to S. P. Kitayev [7]. The processing of ichthyological material was carried out by the standard techniques. Collecting the material was carried out from research net non-aqueous catches, counted and weighed [8-10].

The collection of fish-breeding and biological data and their processing were carried out by the standard techniques [11-13]. The technology of receiving sexual products was made by a factory method also by the standard techniques [11]. Gain of the grown-up fishes was determined by the results of control catch. The statistical and technological works of domestic and foreign authors were used $[14,15]$.

\section{Results and their discussion}

Physiographic and morphometric characteristics of Lake Ozgent. Lake Ozgent is located in Zhanakurgansky district a /d of Ozgent of the Kyzylorda region, the lower Syrdariya river at distance of $18 \mathrm{~km}$ from Zhanakurgan also belongs to the Kandaraly system of lakes. The area of a water mirror during a research was made 130 hectares, the length $-3.5 \mathrm{~km}$, the width $-250 \mathrm{~m}$. The flood of Lake Ozgent goes from the Syrdariya river to the collector Musahan with a water outlet length of $1.5 \mathrm{~km}$ to the lake. In the main, the water work occurs from April to September. On the inflow there is a gateway regulator. The maximum depth at a research made $4 \mathrm{~m}$, average depth $-1.2 \mathrm{~m}$. The overwater vegetation is developed averagely, mainly represented by the Potamogeton perfoliatus and Persicaria amphibia. The coastline is overgrown with reed-bush vegetation, which makes $30 \%$ of water coatings. According to the classification (zoning) of lakes accepted in RK for lake commodity fish breeding, Lake Ozgent refers to the III lake-commercial fishing area.

Hydrochemical mode of Lake Ozgent. Sampling and studying hydrochemical parameters were carried out on all water area of the Ozgent Reservoir. The central open part of the reservoir is characterized by a high transparency of water. The transparency of water on the disk Sekki changed ranging from 0.9 up to $1.1 \mathrm{~m}$. According to the analysis results, the general hardness of water made $15 \mathrm{~mol} / \mathrm{dm}^{3}$, which demonstrates a rigid value, characteristic of many reservoirs with water supply from the Syrdarya river. The content of dissolved oxygen was within normal saturation, average value on the lake is $6.58 \mathrm{mg} / \mathrm{dm}^{3}$. In general, the oxygen mode is favorable for hydrobionts, which is typical for this reservoir. On all water area of the lake carbon dioxide was absent. Content of organic matter was in limits of $3.08 \mathrm{mg} \mathrm{O} / \mathrm{dm}^{3}$, increase in water level during the spring periods with increase in volume of water masses, because of high floods on the rivers, obviously, promote reduction of the concentration of products of destruction of the water plants. Hydrochemical indicators of Lake Ozgent are given in Table 1.

Table 1

\section{Hydrochemical indicators of Lake Ozgent}

\begin{tabular}{|c|c|c|c|c|c|c|c|c|c|c|c|}
\hline \multirow{2}{*}{$\mathbf{p H}$} & \multirow{2}{*}{\begin{tabular}{|c|}
$\mathrm{O}_{2}$ \\
$\mathrm{mg} / \mathbf{d m}^{3}$
\end{tabular}} & \multirow{2}{*}{$\mathrm{CO}_{2}$} & \multirow{2}{*}{$\begin{array}{c}\text { Permanganate } \\
\text { Oxidability, } \mathrm{мгO} / \mathrm{dm}^{3}\end{array}$} & \multicolumn{2}{|c|}{ Biogenic compounds, $\mathrm{mg} / \mathrm{dm}^{3}$} & \multicolumn{5}{|c|}{ Heavy metals, $\mathrm{mg} / \mathrm{dm}^{3}$} & \multirow{2}{*}{$\begin{array}{c}\text { Mineralization, } \\
\mathbf{m g} / \mathbf{d m}^{3}\end{array}$} \\
\hline & & & & $\mathrm{NO}_{2}$ & $\mathrm{NO}_{3}$ & $\mathbf{P b}$ & Cd & $\mathrm{Cu}$ & Zn & As & \\
\hline 7,00 & 6,58 & abs & 3,08 & 0,2 & 0,5 & abs & abs & abs & 0,043 & abs & 1612 \\
\hline
\end{tabular}

The water on the lake differed by the low content of biogenous compounds. The content of nitrites was registered in concentration $0.2 \mathrm{mg} / \mathrm{dm}^{3}$, and nitrates $-0.5 \mathrm{mg} / \mathrm{dm}^{3}$, which testifies the excesses of the nitrite ions for the values of fishery maximum permissible concentration (MPC). The ionic composition in the lake water, according to O. A. Alekin's qualification, is saltish, by a chloride class to magnesium group, in the summer in rare instances it passes in the calcium-sodium group. In general, the ionic composition of the lake water is stable both on seasons, and on the water area of a reservoir. 


\section{Analysis of a food supply of fishes in Lake Ozgent}

Zooplankton. Plankto-fauna of the reservoir during summer observations included four groups of organisms - rotifer (Rotatoria), two groups of copepoda of crustaceans (Diaptomidae and Cyclopidae) and crustaceans (Cladocera). The largest frequency of occurrence characterized the following types: Brachionus angularis Gosse (1851), Keratella quadrata (Müller, 1786), Keratella valga (Echrenberg, 1834), Cyclops vicinus Uljanin (1875), Chydorus sphaericus (O. F. Müller), Bosmina longirostris (O. F. Müller). Data on the number and biomass of zooplankton of Lake Ozgent are given in Table 2.

Table 2

Quantitative characteristic (number, biomass) of the main groups of zooplankton of Lake Ozgent

\begin{tabular}{|l|c|c|}
\hline \multicolumn{1}{|c|}{ Group name } & Number, $\mathbf{e x p} / \mathbf{m}^{\mathbf{3}}$ & Biomass, $\mathbf{~ m g} / \mathbf{m}^{\mathbf{3}}$ \\
\hline Rotatoria & 23000 & 8,02 \\
\hline Diaptomidae & 1250 & 128,00 \\
\hline Cyclopidae & 33808 & 332,91 \\
\hline Cladocera & 19941 & 195,79 \\
\hline Total & 77999 & 664,21 \\
\hline
\end{tabular}

As it can be seen from the Table, the total number of zooplankton during the summer period was $77999 \mathrm{ex} / \mathrm{m}^{3}$, the general biomass $-664.21 \mathrm{mg} / \mathrm{m}^{3}$. The level of quantitative development of planktonic organisms corresponded to low feeding of fishes. Biological indicators on a condition of zooplankton (according to a trophy scale of S. P. Kitayev [7]) characterized Lake Ozgent as a reservoir of a low class, $\beta$-oligotrophic type.

Macrozoobenthos. The level of average depth of the lake in sampling points of a macrozoobenthos was about $3 \mathrm{~m}$, the transparency of water $-1.4 \mathrm{~m}$, the average temperature of water thickness of the top layer $-2.3{ }^{\circ} \mathrm{C}$. As for the soil types, the yellow clay silt was most widespread. During the research period in a macrozoobenthos of the lake there were two groups of invertebrates - unavythinecolored ring worms Annelidas (Oligochaeta) and larvae of dipterous insects of the Chironomidae family. Singly encountered oligochettes were represented by the Tubificidae family. Chironomid larvae included Chironominae's subfamily, consisting of two tribes - Tanytarsini (Micropsectra Kieffer, 1911) and Chironomini (genus Chironomus Meigen, 1803). The number and biomass data of the main groups of a macrozoobenthos in Lake Ozgent are given in Table 3.

Table 3

Quantitative characteristic (number, biomass) of the main groups of a macrozoobenthos of Lake Ozgent

\begin{tabular}{|l|c|c|}
\hline \multicolumn{1}{|c|}{ Group of organisms } & Number, $\mathbf{e x p} / \mathbf{m}^{\mathbf{2}}$ & Biomass, $\mathbf{g} / \mathbf{m}^{\mathbf{2}}$ \\
\hline Oligochaeta & 40 & 0,4 \\
\hline Chironomidae & 380 & 5,72 \\
\hline Total & 420 & 6,12 \\
\hline
\end{tabular}

Apparently from the table, the value of total number of a macrozoobenthos reached $420 \mathrm{ex} / \mathrm{m}^{2}$, the general biomass made $6.12 \mathrm{~g} / \mathrm{m}^{2}$. On the level of residual spring biomass of fodder invertebrates Lake Ozgent is the average for fish-bentophagov and refers to the average class, $\beta$-mezotrophic type (on a scale of a trophy of S. P. Kitayev [7]).

Modern structure of a fish fauna of Lake Ozgent. According to experimental catches in 2020 and also share materials of previous years, the fish fauna of Lake Ozgent is presented by the following types - sazan, pike perch, silver carp, bream, crucian, Asp. (Aspius), small fry, chekhon. The main trade types are sazan, small fry, Asp. A short biological characteristic of these types is given below. The specific names and the statuses of the designation of fishes are submitted in Table 4. 
The species composition and the status of designation of fishes in general on the basin

\begin{tabular}{|l|c|}
\hline \multicolumn{1}{|c|}{ Name of type } & Status \\
\hline Aral roach Rutilus rutilus aralensis Berg & Commercial, aboriginal \\
\hline East Bream Abramis brama orientalis Berg & Commercial, aboriginal \\
\hline Aral Sazan Cyprinus caspio aralensis Spitshakow & Commercial, aboriginal \\
\hline Rudd Scardinus erythropthalmus & Commercial, aboriginal \\
\hline Chekhon Pelecus cultratus Linne & Commercial, aboriginal \\
\hline Silver crucian Carassius auratus (Linne) & Commercial, aboriginal \\
\hline Aral asp. Aspius aspius iblioides & Aboriginal, rare \\
\hline Pike perch ordinary Stizostedion lucioperca Linne & Commercial, aboriginal \\
\hline Perch ordinary Perca fluviatilis Linne & Commercial, aboriginal, rare \\
\hline Pike Esox lucius Linne & Commercial, aboriginal \\
\hline Turkestan ide Leuciscus idus oxianus (Kessler) & Commercial, aboriginal \\
\hline Snakehead Channa argus Warpachowskii Berg & Commercial, introdicated, rare \\
\hline Grass carp Ctenopharingodon idella & Commercial, introdicated, rare \\
\hline White silver carp Hypophthalmichthys molitrix Valenc. & Commercial, introdicated \\
\hline Catfish Silurus glanis Linne & Commercial, rare, aboriginal \\
\hline White eye Abramis sapa (Pallas) & Commercial, rare, aboriginal \\
\hline
\end{tabular}

For the period of research work on Lake Ozgent in the fishing instruments, the following fish species were not found: catfish, perch, pike, snakehead, rudd. Thus, the research of a fish fauna of the lake showed that there live 8 commercial fish species. At the same time, in five commercial species, except Asp. (Aspius) and pike perch, nutrition is similar.

Recommendations on the rational operation of Lake Ozgent in the LCFF mode. The conditions of Lake Ozgent e today (at construction of hydraulic engineering constructions) meet the requirements of Criteria of reference of fishery reservoirs and (or) their sites to reservoirs and (or) sites for conducting trade fishery, amateur (sports) fishery, lake commercial fish farms, cage fish-breeding economy (approv. by the Order of the deputy of the Minister of Agriculture of the Republic of Kazakhstan of August 15, 2017 No. 336. No. 15697), it is registered in the Ministry of Justice of the Republic of Kazakhstan on September 18, 2017.

To increase the efficiency of using a reservoir it is necessary to grow up the valuable fish species, which are in demand in this area. For effective operation of Lake Domalak there are given the following recommendations:

- it is necessary to make the maximum catch to decrease the number of the invaluable (weed) fish fauna;

- cleaning the reservoir from the massive water vegetation;

- stocking of the reservoir with valuable commercial species of fish - carp and herbivorous fishes (with landing density from calculation carp of 100-250 pieces/hectare; white silver carp of 100-200 pieces/hectare; grass carp of 20-400 pieces/hectare) and other valuable types in the long term $[14,15]$. The commodity cultivation of fish will be carried out at the expense of a natural food supply;

- to put protecting lattices on a water inlet in order to prevent from penetration non-commercial fish fauna (weed). Here, put the gateway regulator to preserve the agricultural fish species (valuable).

Stocking and carp fishes cultivation in polyculture on the lake Ozgent in the conditions of lake and commodity fish-breeding economy. The meliorative works on preparation of the lake Ozgent were performed not in full in view of short deadlines. Before stocking and during the vegetative season the works on improvement of conditions of cultivation of fishes - cleaning of the highest water vegetation, partial repair of hydroconstructions were conducted. The Stocking of the lake Ozgent was carried out in the middle of April according to these recommendations. The stocking was carried out from calculation on 1 hectare 450 pieces of a fish stock. From them the yearling of carp with an average weight of 27.5 grams - 19500 pieces, the yearling of white silver carp weighing 20 grams - 26000 pieces, the yearling of grass carp weighing 20 grams - 13000 pieces. During cultivation in the lake carried out control of gain of fishes. The analysis of results of cultivation of carp fishes in the conditions of the lake Ozgent showed that this reservoir can be used both for one-year and for two years' cultivation of products of carp fishes (see Table 5). 
Results of cultivation of yearlings of a carp and herbivorous fishes in Lake Ozgent

\begin{tabular}{|c|c|c|c|}
\hline \multirow{2}{*}{ Index } & \multicolumn{3}{|c|}{ Type of fish } \\
\hline & Carp & White silver carp & Grass carp \\
\hline The duration of cultivation, day & \multicolumn{3}{|c|}{158} \\
\hline $\begin{array}{l}\text { Piece, } \mathrm{g}(x \pm m) \text { : } \\
\text { when landing } \\
\text { at the last control catch }\end{array}$ & $\begin{aligned} 27,5 & \pm 4,9 \\
413,1 & \pm 12,8\end{aligned}$ & $\begin{array}{c}20,0 \pm 2,2 \\
321,4 \pm 9,9\end{array}$ & $\begin{array}{c}20 \pm 3,8 \\
448,7 \pm 10,1\end{array}$ \\
\hline Absolute increase, $\mathrm{g}$ & 385,6 & 301,4 & 428,7 \\
\hline Average daily increase, $\mathrm{g}$ & 2,44 & 1,9 & 2,7 \\
\hline Landing density, exp/ha & 150 & 200 & 100 \\
\hline The coefficient of commercial return, $\%$ & 70 & 70 & 30 \\
\hline Planned fish productivity in $2020, \mathrm{~kg} / \mathrm{ha}$ & 43,4 & 45 & 13,5 \\
\hline Overall fish productivity, $\mathrm{kg} / \mathrm{ha}$ & \multicolumn{3}{|c|}{101,9} \\
\hline Implemented fish product standards adopted for southern zone, $\mathrm{kg} / \mathrm{ha}$ [15] & \multicolumn{3}{|c|}{120} \\
\hline
\end{tabular}

However, the average weight of the grown-up two-year-old carps and herbivorous fishes is not in demand in the market. It is possible to organize a partial catch of large fish by installing the network, which will have a positive effect on the growth of the remaining fish.

\section{Conclusions}

The analysis of results of cultivating two-year-old carp species in the conditions of Lake Ozgent showed that pure gain in 5 months of cultivation (on extensive technology when using only the natural food supply) was $385.6 \mathrm{~g}$ at carp, $301.4 \mathrm{~g}$ at white silver carp and $428.7 \mathrm{~g}$ at grass carp. Due to organization of full catch of commodity fish the overall fish productivity of Lake Ozgent will make $101.9 \mathrm{~kg} / \mathrm{hectare}$, of them on carp - $43.4 \mathrm{~kg} / \mathrm{hectare}$, along grass carp - $13.5 \mathrm{~kg} /$ hectare and white silver carp - $45 \mathrm{~kg} /$ hectare. The gain of the grown-up fish in Lake Ozgent corresponds to biotechnical standards for cultivation of fishes in feeding lakes in polyculture.

\section{REFERENCES}

1. Lurye Yu. Yu. The unified analysis methods of waters. Moscow, Chemistry Publ., 1973. $376 \mathrm{p}$.

2. Alyokin O. A. Methods for research the physical properties and chemical composition of water. Life of fresh waters of the USSR. Moscow; Leningrad, 1959. Vol. IV. Part 2. 302 p.

3. Sharapova L. I., Falomeeva A. P. Methodical manual at hydrobiological fishery researches of reservoirs of Kazakhstan (plankton, zoobenthos). Almaty, 2006. $27 \mathrm{p}$.

4. The determinant of freshwater invertebrates of the European part of the USSR. Resp. edit. L. A. Kutikova and Ya. I. Starobogatov. Leningrad, Gidrometeoizdat, 1977. 512 p.

5. Balushkina E. V., Vinberg G. G. Dependence between the weight and length of a body at planktonic animals. General bases of studying of water ecosystems. Leningrad, Science Publ., 1979. Pp. 169-172.

6. Pankratova V. Ya. Larvae and dolls of mosquitoes of a subfamily of Podonominae and Tanypodinae of fauna of the USSR. Leningrad, 1977. $154 \mathrm{p}$.

7. Kitayev S. P. About a ratio of some trophic levels and "trophy scales" of lakes of different natural zones. $\mathrm{Te}$ zisy dokladov V Congressa Vsesoiuznogo gidrobiologicheskogo obshchestva (Tol'iatti, 15-19 sentiabria 1986 g.). Kuibyshev, 1986. Part 2. Pp. 254-255.

8. Pravdin I. F. Study guide of fishes. Moscow, Food industry Publ., 1966. 376 p.

9. Chugunova N. I. Methods of studying of age and growth of fishes. Moscow, Soviet science Publ., 1952. $116 \mathrm{p}$.

10. Melnikova A. G. Estimation of fish reserves in the reservoir for catching by set of pilot networks. Materialy nauchno-prakticheskoi konferentsii (5-6 noiabria 2008 g.). Perm, 2008. 168 p.

11. Collection of regulatory and technological documentation on commodity fish breeding. Moscow, Agropromizdat, 1986. Vol. 1. 261 p.

12. Assylbekova S. Zh., Isbekov K. B., Kulikov E. V. Recommendations for users of nature and farmers about the organization and technological cycle LCFBE (lake and commodity fish-breeding economy). Almaty, 2014. Pp. 16-17.

13. Kozlov V. I. Reference book for the farmer-fish breeders. Moscow, VNIRO Publ., 1998. 342 p.

14. Assylbekova S. Zh., Kulikov E. V., Kulikova E. V., Tsoi V. N., etc. Methodical recommendations for nature users and farmers about the organization and a technological cycle of LCFF. Almaty, 2013. $171 \mathrm{p}$.

15. Ryzhkov L. P. Lake commodity fish breeding. Moscow, Agropromizdat, 1987. 336 p.

The article submitted to the editors 13.04.2021 


\title{
INFORMATION ABOUT THE AUTHORS
}

Nailya B. Bulavina - Senior Researcher of the Laboratory of Aquaculture; Fisheries Research and Production Center, LLP; Republic of Kazakhstan, 050010, Almaty; bulavina@fishrpc.kz.

Tynysbek T. Barakbayev - Head of the Aral branch; Fisheries Research and Production Center, LLP; Republic of Kazakhstan, 050010, Almaty; barakbayev@fishrpc.kz.

Galymzhan Zh. Iskhakhov - Researcher of the Aral branch; Fisheries Research and Production Center, LLP; Republic of Kazakhstan, 050010, Almaty; galim_jan93@mail.ru.

Alyona A. Mukhramova - Chief Academic Secretary; Fisheries Research and Production Center, LLP; Republic of Kazakhstan, 050010, Almaty; mukhramova@fishrpc.kz.

\section{ОПЫТ ОРГАНИЗАЦИИ ОЗЕРНО-ТОВАРНОГО РЫБОВОДНОГО ХОЗЯЙСТВА В УСЛОВИЯХ ОЗЕРА ОЗГЕНТ}

\author{
Н. Б. Булавина, Т. Т. Баракбаев, Г. Ж. Исхахов, А. А. Мухрамова \\ ТОО «Научно-производственный цеентр рыбного хозяйства», \\ Алматы, Республика Казахстан
}

\begin{abstract}
Приведены результаты исследований, проведенных на оз. Озгент (Кызылординская обл.). Были собраны и проанализированы данные гидрохимического режима озера, ионного состава, данные о содержании биогенных соединений, кислородном и термическом режимах. Проведена оценка кормовой базы и современного состояния ихтиофауны. По полученным данным были разработаны рекомендации по использованию оз. Озгент, проведены рекомендованные мелиоративные мероприятия (мелиоративный лов, ремонт гидросооружений) и зарыбление рыбопосадочным материалом карповых рыб. По итогам работ установлено, что в условиях оз. Озгент абсолютный прирост за 5 месяцев выращивания (по экстенсивной технологии, при использовании только естественной кормовой базы) составил 385,6 г у карпа, 301,4 г у белого толстолобика и 428,7 г у белого амура. При организации полного вылова товарной рыбы общая рыбопродуктивность оз. Озгент составит 101,9 кг/га, из них по карпу - 43,4 кг/га, по амуру - 13,5 кг/га, по белому толстолобику - 45 кг/га. Прирост выращенной рыбы в оз. Озгент соответствует биотехническим нормативам по выращиванию рыб в нагульных озерах в поликультуре.
\end{abstract}

Ключевые слова: рыболовство, озеро Озгент, гидрохимические показатели, карповые рыбы, выращивание, прирост.

Для цитирования: Булавина Н. Б., Баракбаев Т. Т., Исхахов Г. Ж., Мухрамова А. А. Опыт организации озерно-товарного рыбоводного хозяйства в условиях озера Озгент // Вестник Астраханского государственного технического университета. Серия: Рыбное хозяйство. 2021. № 2. C. 90-96. DOI: 10.24143/2073-5529-2021-2-90-96.

\section{СПИСОК ЛИТЕРАТУРЫ}

1. Lurye Yu. Yu. The unified analysis methods of waters. M.: Chemistry, 1973. 376 p.

2. Alyokin $O$. A. Methods for research the physical properties and chemical composition of water // Life of fresh waters of the USSR. M.-L., 1959. V. IV. Part 2. 302 p.

3. Sharapova L. I., Falomeeva A. P. Methodical manual at hydrobiological fishery researches of reservoirs of Kazakhstan (plankton, zoobenthos). Almaty, 2006. 27 p.

4. The determinant of freshwater invertebrates of the European part of the USSR / resp. edit. L. A. Kutikova and Ya. I. Starobogatov. L.: Gidrometeoizdat, 1977. 512 p.

5. Balushkina E. V., Vinberg G. G. Dependence between the weight and length of a body at planktonic animals // General bases of studying of water ecosystems. L.: Science, 1979. P. 169-172. 
6. Pankratova V. Ya. Larvae and dolls of mosquitoes of a subfamily of Podonominae and Tanypodinae of fauna of the USSR. L., 1977. $154 \mathrm{p}$.

7. Kitayev S. P. About a ratio of some trophic levels and "trophy scales" of lakes of different natural zones // Тез. докл. V Конгресса Всесоюз. гидробиологич. о-ва (Тольятти, 15-19 сентября 1986 г.). Куйбышев, 1986. Ч. 2. C. 254-255.

8. Pravdin I. F. Study guide of fishes. M.: Food industry, 1966. 376 p.

9. Chugunova N. I. Methods of studying of age and growth of fishes. M.: Soviet science, 1952. $116 \mathrm{p}$.

10. Melnikova A. G. Estimation of fish reserves in the reservoir for catching by set of pilot networks // Maтериалы науч.-практ. конф. (5-6 ноября 2008 г.). Пермь, 2008. 168 с.

11. Collection of regulatory and technological documentation on commodity fish breeding. M.: Agropromizdat, 1986. V. 1. 261 p.

12. Assylbekova S. Zh., Isbekov K. B., Kulikov E. V. Recommendations for users of nature and farmers about the organization and technological cycle LCFBE (lake and commodity fish-breeding economy). Almaty, 2014. P. 16-17.

13. Kozlov V. I. Reference book for the farmer-fish breeders. M.: VNIRO, 1998. 342 p.

14. Assylbekova S. Zh., Kulikov E. V., Kulikova E. V., Tsoi V. N., etc. Methodical recommendations for nature users and farmers about the organization and a technological cycle of LCFF. Almaty, 2013. $171 \mathrm{p}$.

15. Ryzhkov L. P. Lake commodity fish breeding. M.: Agropromizdat, 1987. 336 p.

Статья поступила в редакцию 13.04.2021

\section{ИНФОРМАЦИЯ ОБ АВТОРАХ}

Наиля Баймуратовна Булавина - старший научный сотрудник лаборатории аквакультуры; ТОО «Научно-производственный центр рыбного хозяйства»; Республика Казахстан, 050016, Алматы; bulavina@fishrpc.kz.

Тынысбек Темирханович Баракбаев - директор Аральского филиала; ТОО «Научно-производственный центр рыбного хозяйства»; Республика Казахстан, 050016, Алматы; barakbayev@fishrpc.kz.

Галымжжан Жолдасбекович Исхахов - научный сотрудник Аральского филиала; ТОО «Научно-производственный центр рыбного хозяйства»; Республика Казахстан, 050016, Алматы; galim_jan93@mail.ru.

Алена Александровна Мухрамова - главный ученый секретарь; ТОО «Научно-производственный центр рыбного хозяйства»; Республика Казахстан, 050016, Алматы; mukhramova@fishrpc.kz. 